Full length article

\title{
GEOLOGICAL AND PETROGRAPHICAL CHARACTERISTICS OF SORAP MASSIF GABBROS, RAS-KOH OPHIOLITE, BALOCHISTAN, WESTERN PAKISTAN
}

Ali Muhammad, Abdul Ghaffar*, Inayat Ullah, M. Ishaq Kakar, Fida Murad

Centre of Excellence in Mineralogy, University of Balochistan, Quetta, Pakistan

\section{ABSTRACT}

This study discussed the Sorap Massif which is the ophiolitic fragment composed of the upper mantle and lower crustal section of an ophiolitic sequence. An ophiolitic sequence in Sorap Massif consists of harzburgite, dunite, large distant units of serpentinized wehrlite intrusion and outcrop of confined layered gabbro covered by the Quaternary sand dunes. The basal part of gabbroic intrusion is in contact with mantle rocks and the upper part is juxtaposed with the Kuchakki Volcanic Group. On outcrop-level and in hand specimen, the gabbros exhibit needle-like ferromagnesian minerals including hornblende associated with plagioclase and pyroxene. Petrographically the gabbros are classified into norite, gabbro norite and gabbro. The mineral constituents of norite are plagioclase, orthopyroxene and amphibole, gabbro norite is consists of equal constituents of orthopyroxene and clinopyroxene, plagioclase and amphibole and the gabbro is composed of clinopyroxene, plagioclase and amphibole. The high constituents of minerals such as pyroxene, amphibole and low constituents of olivine in the Sorap gabbros indicates that these gabbros are formed by the immature part of the oceanic plate with dehydration of the oceanic plate subduction.

KEYWORDS: Sorap Massif, Ras-Koh Ophiolites, Kuchakki Volcanic, Gabbro, Ocean plate subduction

*Corresponding author: (Email: ghaffar.chagai@gmail.com)

\section{INTRODUCTION}

An ophiolite is a distinctive rock unit of ultramafic-mafic rocks sequence from bottom to the top including serpentinized ultramafic rocks at the base, gabbroic rocks periodically indicated the cumulate texture, complex of mafic sheeted dikes and mafic volcanic rock associated with distinctive bodies of chromite, sodic constituents of felsic types of igneous rock overlying with pelagic sedimentary rocks (1). In 1813 the French Mineralogist Alexander
Brongniart has first introduced the Ophiolite regarding serpentine in the mélanges, according to his subsequently redefined the definition of an ophiolite to include a suite of ultramafic to mafic types of magmatic rocks that occurred in the Apennines (2). Gustav Steinmann (1927) elevated the term ophiolite to a modern concept, he said that the ophiolite is spatially associated with kindred rocks that are originated in the suite of intrusion in the axial part of geosynclines. The genetic model and definition of ophiolite have been varied. Still, it is 
mainly accepted that the ophiolite indicates that the oceanic crust has been emplaced onto the continents (3). An ophiolite expresses the fragments of the upper mantle and oceanic-crust $(4,5,6)$, that were integrated on the margins of continental crust arc-continent and continent-continent collision (7), ridgetrench interaction (8, 9) and subduction accretion (10). An ophiolite has widely occurred along the suture zone in both accretionary and collisional types in the orogenic belt, which demarks the tectonic boundaries between two plates or accreted terranes (11). Specific analysis of well-exposed ophiolite last two decades indicated that the main ophiolite formed in the supra-subduction tectonic setting in the upper part of the convergent plate and not occurred in the mid-oceanic ridge spreading centers $(12,13,14)$. An ophiolite is a distinctive rocks unit of ultramafic - mafic rocks sequence from bottom to the top including a serpentinized ultramafic rock, gabbroic rocks periodically indicated the cumulate texture, complex of mafic sheeted dikes and mafic volcanic rock associated with distinctive bodies of chromite, sodic constituents of felsic types of igneous rock overlying with sedimentary rock units such as chert, shale and minor bed of limestone (5). Gabbros are formed by the basaltic magma, which is raised from the underlying mantle and as well as formed by the slow cooling in the magma chamber (15). Gabbros are essentials parts of the crustal section of an ophiolitic suite from bottom to the top including a layered gabbro in the basal part of the crustal section and isotropic to foliated gabbros at the top of the crustal section. In the worldwide well-exposed gabbroic section is widely exposed in the Semail ophiolite in Oman and Bay of Island ophiolite in Newfoundland Canada $(6,16)$. Geological features of the crustal part of Ras-Koh ophiolite have been early recorded by $(17,18)$. Until there is no detailed geological study of the gabbroic section of Sorap Massif in the Ras-Koh ophiolite. In this paper, we are going to discuss the geological and petrological features of the gabbroic rock units from Sorap Massif in the RasKoh ophiolite by using their field features and petrography results.

\section{GEOLOGICAL SETTING OF RAS-KOH ARC}

Ras-Koh Arc is the southern part of Chagai-RasKoh double chain arc system (19), trending NE to SW direction and about $250 \mathrm{~km}$ long in E-W direction and $40 \mathrm{~km}$ wide in N-S direction (20, 21). The northern margin of the Ras-Koh range is border by the Dalbandin Trough, from the east it is terminated by the Noshki-Chaman Fault, from the west it is ended by Hari Rud fault while it is covered by the Quaternary alluvial and sand dune of the Kharan desert in the south (Fig.1) (22). The NE to SW trending direction of the RasKoh volcanic arc is disputed to the $\mathrm{E}$ to $\mathrm{W}$ trending direction of the Chagai-Magmatic arc which is considered the frontal arc of the Chagai-Ras-Koh arc system $(23,24)$. The southern part of Ras-Koh Range is bounded by the fore arc basin to Makran coast area mainly comprised up flysch types of sediments called Makran accretionary wedge. Makran accretionary wedge deformed thick zone 
developed by the prolonged northward deposition of marine sediments during the Eocene to Miocene periods. Combine the accretionary prism and fore arc basin is one of the widest trench arc gaps on the earth $(25,21)$. The Ras-Koh ophiolite is located in the western part of the Ras-Koh range, it can be distinguished by the two main localities in this range, i.e., Bunap intrusion and Sorap Massif. These ophiolites are intensely serpentinized harzburgite outcrops in the Bunap area and moderately weathered in the Sorap Massif at the western margin in the Ras-Koh range (Fig.1). Mainly the outcrops are faulted and thrusted occurred along the parallel fault in the main trend of the range. The red conglomerate mainly consists of basaltic fragments and cherty pebbles associated with serpentines at different localities that indicate the Late Cretaceous weathering and sub-areal exposure of the ophiolites, it may be formed before the deposition of the Late Cretaceous to Paleocene Rakhshani Formation (17).

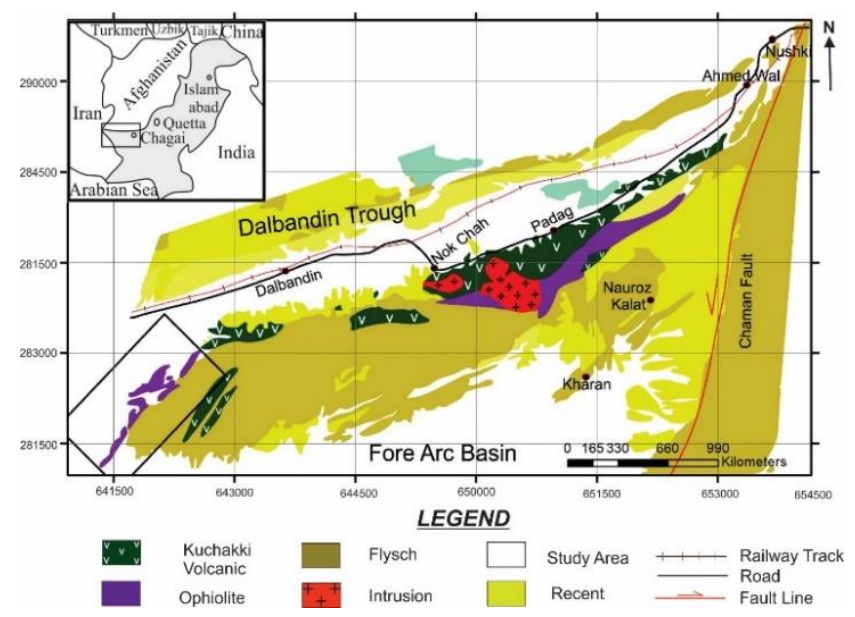

Figure.1. Simplified Tectonic and geological map of Ras-Koh Arc, showing the distribution of lithological units and Ras-Koh ophiolite in the region (20).

Stratigraphic sequence of the Ras-Koh Range comprised of Early to Late Jurassic Ras-Koh to subrecent-recent alluvial deposits. Early to Late Jurassic accretionary complex mainly consists of Bunap sedimentary complex, Charkohan radiolarian chert and Ras-Koh ophiolitic mélanges. Late Cretaceous Kuchakki Volcanic Group mainly composed of basaltic to the andesitic lava flow and volcanic clast including agglomerate, tuff, lapilli tuff, breccia and volcanic conglomerate associated with sandstone, limestone, mudstone siltstone and radiolarian chert (20, 18). Paleocene Rakhshani Formation is composed of volcanic flysch subordinated with sandstone intercalation of shale, mudstone and limestone indicating a turbidities sequence $(26,20$, 18). Eocene Kharan Limestone comprised of medium to thick-bedded of fossiliferous to argillaceous limestone, Eocene to Oligocene Nauroze Formation dominantly shale interbedded with sandstone and minor thin-bedded of limestone and conglomerate and Miocene to Pliocene Dalbandin Formation composed of shale subordinate with sandstone, shale and conglomerate capped by the sub recent to recent gravel, sand, silt and clay (Fig.2) $(20,18,22)$. 


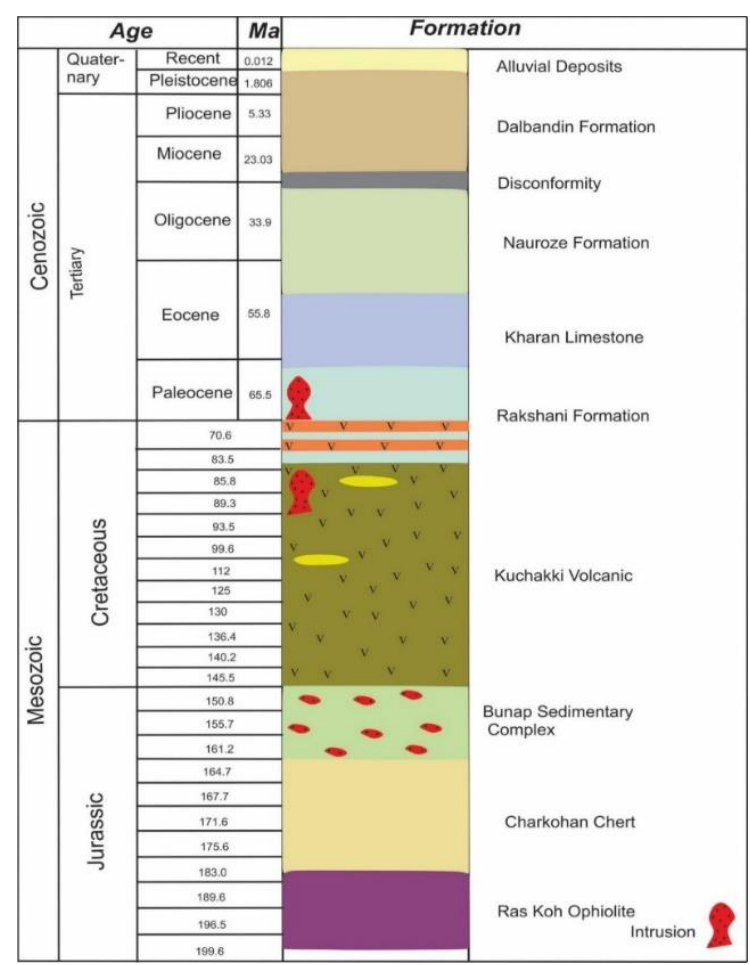

Figure.2. Generalized stratigraphic column of Ras-Koh $\operatorname{Arc}(18)$.

\section{GEOLOGY OF SORAP MASSIF AND GABBROS}

Ophiolitic outcrops in Sorap Massif at the western part of Ras-Koh range covered by the transition from the upper mantle to the lower crustal section of an ophiolitic sequence. Ophiolite sequence is mainly composed of harzburgite, dunite, large distinct units of serpentinized wehrlite intrusion and an outcrop of confined layered gabbro covered by the sand dune in the Sorap Massif (Fig.3). The crustmantle transition zone (Moho) is somewhere exposed in the study area. Low grade disseminated to nodular chromite ore is currently mined at three localities in the Sorap Massif (Fig.3) (17). Since neither a metamorphic sole nor the upper part of a classic ophiolite series has been discovered (1), we can only conclude that the outcrops of the Sorap region are tectonically less affected equivalents of the Bunap ophiolite based on their similar tectonic location above the Kuchakki Volcanic Group. Outcrop of gabbroic intrusion of Sorap Massif is located in the southwest, approximately 40 to $60 \mathrm{Km}$ from Dalbandin.

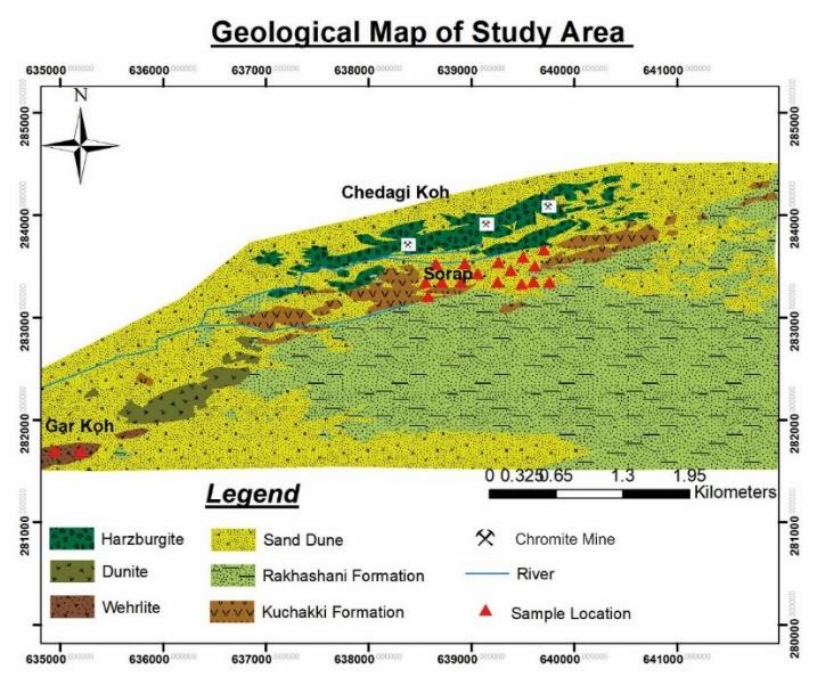

Figure.3. The geological map illustrates the study area in the Sorap Massif in Ras-Koh Ophiolite (17).

In fieldwork, the geological mapping and lithological characteristics have defined the rock composition and length of gabbroic intrusion of Sorap Massif. The field features of Sorap Massif mainly composed up basic types of gabbroic rock units. The gabbro intrusion is trending from the north-east to south-east direction from eastern to the western part of Sorap Massif area. In the eastern part of the study area in Sorap Kaur (Nala) intrusion of gabbroic rock units' basal part of gabbroic intrusion mainly composed of mantle rock units harzburgite, mylonitic peridotite, dunite with close jointing of gabbro, contact with the Cretaceous Kuchakki Volcanic Group and covered by the Quaternary sand dune (Fig.4ab). In the central part of the study area, the outcrop of gabbroic rock units mainly 
composed of needle-like dark ferromagnesian minerals i.e., hornblende associated with light minerals plagioclase (Fig.4C). This part of the gabbro mainly consists of a foliated-like structure because of the intense condition of pressure due to elastic deformation during emplacement. In the western part of the study area, the intrusion of gabbroic rock units is associated with dunite in the Gar-Koh area. In this area the gabbroic outcrop covers $1-1.5 \mathrm{Km}^{2}$, the rock units in this area are associated with concordant to dis-concordant layered of harzburgite, dunite and pegmatite vein within the gabbroic intrusion in the wehrlite rock units (Fig.4d-f).
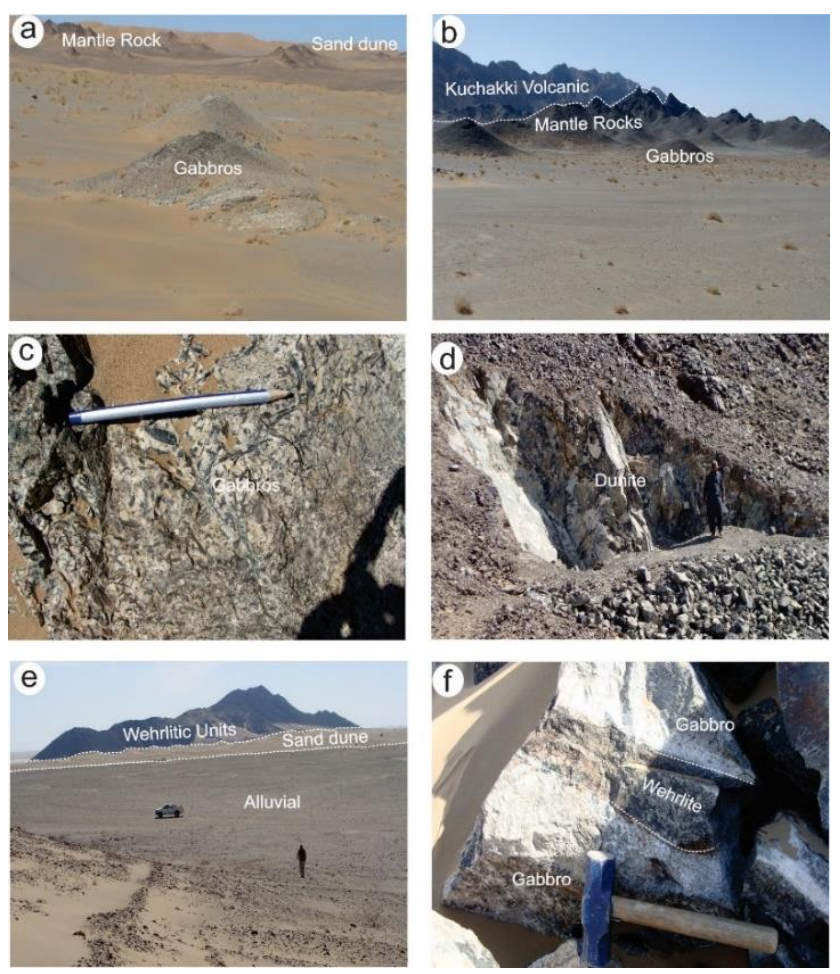

Figure 4 a-f. Field features of the Sorap Massif; Mantle rock units contact with Kuchakki Volcanic Group and Gabbroic rock units covered with sand dune (a and b). Gabbroic units consist of needle-like ferromagnesian minerals with light coarse grains of plagioclase (c). Ophiolitic rock (Dunite) is mined for chromite (d). Wehrlite is covered by the quaternary alluvial, sand dune and interlayered with gabbro (e and f).

\section{MATERIALS AND METHODS}

Detailed geological fieldwork of two weeks was conducted in the Sorap Massif in the Ras-Koh Ophiolitic belt. During the fieldwork, the area was geologically mapped, described all-field features of the ophiolite, identified the lithological units and collected the twenty least altered samples for laboratory analysis. After that, the thin sections of eighteen least altered samples were prepared for petrographic study. The study of the petrographic thin section was carried out on Leica DM 750 digital polarized microscope in the Centre of Excellence Mineralogy, University of Balochistan (CEMUOB).

\section{RESULTS}

\subsubsection{Norite}

Norite is mainly composed of plagioclase, orthopyroxene, amphibole, secondary minerals are sericite, chlorite and minor constituents of serpentine and accessory minerals are including epidote, apatite and opaque minerals. The texture is interlocking and subophitic, medium to coarse-grain of plagioclase, orthopyroxene, fine to medium grain amphibole with fine grain sericite and chlorite. Crystal shapes of medium to coarse grains have subhedral to euhedral crystal shape and fine grains have anhedral to partially subhedral crystal shape (Fig.5a-b). Plagioclase has medium to coarse grain texture, euhedral elongated laths crystal shape with 
albite twining, $1^{\text {st }}$ order interference color in cross-polarized light. In plane-polarized light, the plagioclase has colorless to white interference color with low to moderate relief. Orthopyroxenes have coarse grain texture, euhedral crystal shape with prismatic crystal structure and sample and lamellar twinning, highly pleochroism with $2^{\text {nd }}$ to $3^{\text {rd }}$ order interference color and right-angle welldeveloped cleavage with parallel extension in cross-polarized light and plane-polarized light orthopyroxene have colorless to greenish interference color with moderate to high relief. Amphibole has fine to coarse texture, subhedral to euhedral crystal shape, $2^{\text {nd }}$ order interference color and has a double set $56^{\circ}$ to $126^{\circ}$ angle of cleavages in cross-polarized light and planepolarized light the amphibole has high greenish to brownish pleochroic with moderate relief.

Model constituents of norite is; plagioclase (44 $69.28 \%)$, orthopyroxene (18.3 - 28\%) and Amphibole (5 - 10\%).

\subsubsection{Gabbro Norite}

Gabbro norite mainly consists of plagioclase, equal constituents of orthopyroxene and clinopyroxene, amphibole with secondary minerals are sericite, chlorite and accessory minerals are epidote, apatite and opaque minerals. Gabbro norite has ophitic to subophitic and granular textures. Pyroxene grains are enclosed by plagioclase grains. In gabbro norite, the plagioclase grains are partially altered into sericite and pyroxene grains are intense to partially altered into the chlorite (Fig.5.c-d).
Plagioclase has medium to coarse grain texture, subhedral elongated crystal shape with regular polysynthetic twinning and partially altered into sericite. Pyroxene grains are enclosed by the plagioclase have a double set of cleavage with an irregular fracture with anhedral to subhedral crystal shape with $2^{\text {nd }}$ to $3^{\text {rd }}$ order interference color and highly pleochroic with moderate to high relief. Pyroxene is intensely altered into chlorite.

Model constituents of gabbro norite is; plagioclase (58.57 - 62.82\%), orthopyroxene $(11.66-25.71 \%)$, clinopyroxene (12.85 - 23.21) and Amphibole (6.66 - 12.14\%).

\subsubsection{Gabbro}

Gabbro is mineralogically composed of high constituents of the primary minerals plagioclase, clinopyroxene and amphibole, secondary minerals are high constituents of sericite and chlorite with accessory minerals are including epidote, apatite and opaque minerals. Gabbro has sub-ophitic to interlocking texture between plagioclase and clinopyroxene grains. In a few thin sections, mediums to coarse grains laths of plagioclase and clinopyroxene are bounded by the fine grain chlorite and sericite in the groundmass. The main texture types identified are poikilitic and granular. In poikilitic texture, the coarse grain clinopyroxene is enclosed by the fine to medium grains laths of plagioclase (Fig.5e-f).

In gabbro, the plagioclase has medium to coarse grain texture, subhedral to euhedral crystal shape with pericline to albite twining, $1^{\text {st }}$ 
order interference in cross-polarized light and plane-polarized light. It has a colorless to white interference color with low to moderate relief. In a few thin sections, the plagioclase is intensely altered into secondary minerals sericite. Clinopyroxene has medium to coarse grain texture, subhedral to euhedral crystal shape with sample and a lamellar twin along the composition plane, $2^{\text {nd }}$ to $3^{\text {rd }}$ order interference color has pale green, pale brown, brown and pink color, perfect cleavage and irregular fracture with incline extinction along the cleavage angle in cross-polar light. Plane polarized light clinopyroxene has highly greenish pleochroic with moderate to high relief. Aegirine and augite are common members of clinopyroxene mainly occurred in this section.

Model constituents of gabbro is; plagioclase (49.2 - 68.5\%), clinopyroxene (15 - 30\%) and Amphibole (5-10\%).
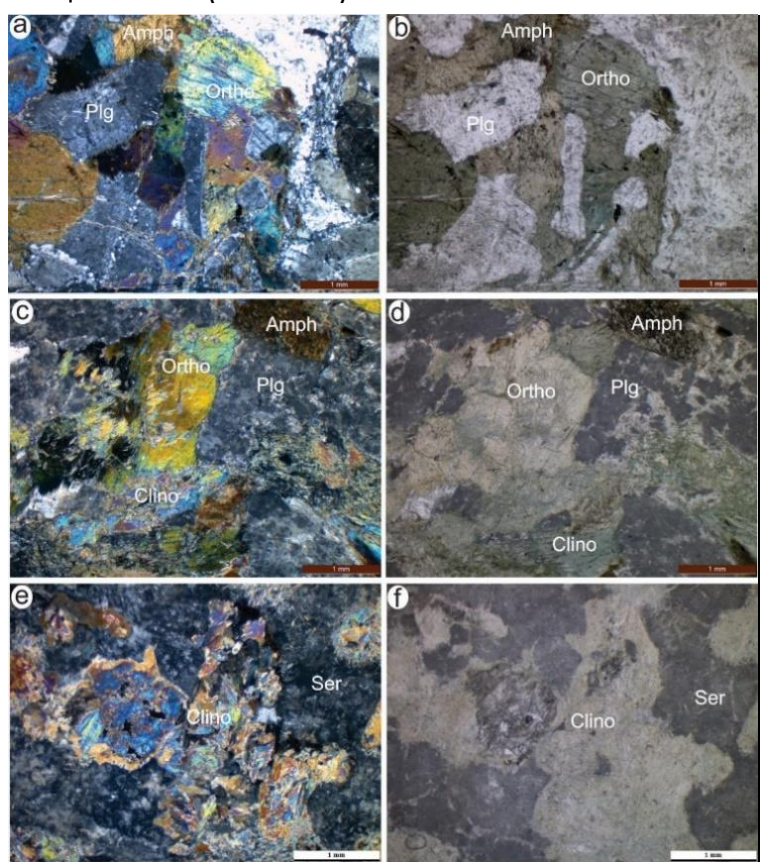

Figure 5.a-f. Petrographic features of the gabbroic rocks of Sorap Massif; Norite is mainly composed of plagioclase, orthopyroxene, amphibole and secondary minerals are sericites with interlocking and subophitic, medium to coarse grain texture ( $a$ and b). Gabbro norite mainly consists of plagioclase, equal constituents of orthopyroxene and clinopyroxene, amphibole and secondary minerals are sericite and chlorite with ophitic to sub-ophitic and granular texture ( $c$ and d). Gabbro is composed of high constituents of plagioclase, clinopyroxene and amphibole, secondary minerals sericite and chlorite with ophitic to the interlocking texture (e and f).

\subsection{Comparison of Sorap Massif Ras-Koh gabbros with Khanozai Muslim Bagh Ophiolites}

Gabbroic rock units in Sorap Massif in the RasKoh Ophiolitic belt are basal parts of the crustal section of ophiolite and that are formed in the magma chamber by the processes of crustal fractionation. The Sorap Massif is a western segment of Ras-Koh Ophiolite and Sorap Massif has an immature sequence of intrusion of gabbroic rocks in its crustal section mainly composed of ultramafic to mafic cumulates including a harzburgite, mylonitic peridotite and dunite covered by the basaltic-andesitic volcanic rock units and quaternary alluvial sediments and sequence of pelagic sediments are absence in the Ras-Koh Ophiolitic belt. These characteristics of an immature sequence of intrusion of gabbroic rock units in the crustal section are also recorded in a major ophiolitic belt around the world, i.e. ophiolitic belt in the Tethyan oceanic region including a Troodos Cyprus, Kizildag and Pozanti Karsanti Turkey, Pindos Greece, Semail Oman, Bela and Muslim Bagh Pakistan, Xigaze Tibet $(5,27,28,29,30,31$, $32,15,33)$. 
The intrusion of gabbroic rock units in the crustal part of Sorap Massif in the Ras-Koh Ophiolite consists of a cyclic succession of ultra-mafic to mafic cumulates from bottom to top including a harzburgite, mylonitic peridotite, dunite, wehrlite and gabbro. Gabbroic rock units are classified into norite, gabbro norite and gabbro. Repeated series of each cyclic succession has different rock composition, structure and thickness because of the various phase of crystallization of minerals constituents due to differential supplied of magma in the magma chamber (34). The minerals constituents of gabbroic rock units of Sorap Massif in the RasKoh Ophiolite enriched pyroxene and amphibole, that is crystallized in the intrusion of gabbroic rock units indicating an immature part of oceanic plate and dehydration part of subduction plate. These features are indicated the model of gabbroic intrusion of Sorap Massif in the Ras-Koh ophiolite is originated in the large magma chamber by the magmatic processes linked with subduction.

According to Popal the intrusion in the crustal part of Khanozai Ophiolite mainly consist of cyclic series of ultra-mafic to mafic cumulates including dunite, pyroxenite, wehrlite and gabbro. The gabbroic rock units are classified into olivine gabbro, gabbronorite, olivine gabbronorite, norite and gabbro (35). The particular cycle of the reciprocated series has various rocks sequence, structures and thickness, that is indicating the numerous phases of crystallization of minerals constituents due to distinctive supplies of magma in the magma chamber (34). The mineral composition of gabbro is enriched in olivine, which is crystallized in the sequence of gabbroic rock units that are indicated the genesis of minerals constituents of gabbros. Mineral constituents of gabbro were formed by the numerous pluses of magma during the stable time of crustal growth (35). These features indicate that the Khanozai gabbroic may have originated from different intervals of time due to different episodes of magmatism. These characteristics of intrusion of the crustal section are also reported from the Muslim Bagh Ophiolite $(14,36)$. The features of Muslim Bagh and Khanozai gabbros indicating that they are not originated from the large magma chamber (37) and they may be formed by the magmatic processes such as the glacier model or sheeted sill model suggested for the ophiolitic gabbro's $(26,38)$.

\section{CONCLUSION}

1. The Sorap massif of Ras-Koh Ophiolite is composed of mantle peridotites, ultramafic cumulates and mafic cumulates.

2. Petrographically, the crustal sequence of Sorap massif is classified as norite, gabbronorite and gabbro.

3. Major constituents of gabbroic rock units are composed of orthopyroxene, clinopyroxene, amphibole and plagioclase associated with secondary minerals and minor constituents of accessory minerals.

4. High constituents of ferromagnesian minerals including pyroxene and amphibole and low constituents of olivine in the gabbroic intrusion these are indicating the tectonic and petrogenesis of gabbroic 
intrusion. The intrusion of gabbroic rock units is formed by the immature part of the oceanic plate and the dehydration part of oceanic plate subduction.

\section{Acknowledgments}

This research was financially supported by the Higher Education Commission, Pakistan under its National Research Program for Universities (NRPU) Project \# 3593 to, M. Ishaq Kakar.

\section{REFERENCES}

[1] Participants. Penros field confress on ophiolite. Geotime, (1972). 17, P. 24-25.

[2] Brongniart, A. Sur le gisement ou position relative des ophiolites, euphotides, jaspes, etc. dans quelques parties des Apennins: Annales des Mines, Paris, (1821). v. 6, p. 177-238.

[3] Steinmann, G. Die ophiolitischen Zonen in den Medi terranean Kettengebirgen: Compte Rendu, XIVe Congres Géologique International, 1926, Madrid, Grafi cas Reunidas. (1927) v. 2, p. 637-667.

[4] Dewey, J.F., and Bird, J.M. The origin and emplacement of the ophiolite suite: Appalachian ophiolites in Newfoundland: Journal of Geophysical Research. (1971) v. 76, p. 3179-3206, doi: 10.1029/JB076i014p03179.

[5] Coleman, R. G. What is an Ophiolite? In Ophiolites (pp. 1-7). Springer, Berlin, Heidelberg. (1977).

[6] Nicolas, A. Structure of Ophiolites and Dynamics of Oceanic Lithosphere: Dordrecht, the Netherlands, Kluwer Academic Publishers. (1989) 367 p.
[7] Dilek, Y., and Flower, M.F.J. Arc-trench rollback and forearc accretion: 2. A model template for ophiolites in Albania, Cyprus, and Oman., Ophiolites in Earth History: Geological Society of London Special Publication, (2003) 218, p. 43-68.

[8] Cloos, M. Lithosphere buoyancy and collisional orogenesis: Subduction of oceanic plateaus, continental margins, island arcs, spreading ridges, and seamounts: Geological Society of America Bulletin, (1993) v. 105, p. 715-737, doi: 10.1130/0016-7606(1993)105 2.3.CO;2.

[9] Lagabrielle, Y., Guivel, C., Maury, R., Bourgois, J., Fourcade, S., and Martin, H. Magmatic-tectonic effects of high thermal regime at the site of active ridge subduction: The Chile triple junction model: Tectonophysics, (2000) v. 326, p. 255-268, doi: 10.1016/ S0040-1951 (00)00124-4.

[10] Cawood, P.A., Kröner, A., Collins, W.J., Kusky, T.M., Mooney, W.D., and Windley, B.F. Accretionary orogens through Earth history in : Cawood, P.A. and Kröner, A. (Eds.), Earth Accretionary Systems in Space and Time, Geological Society of London Special Publication (2009) 318, p. 1-36.

[11] Lister, Gordon, and Marnie Forster. "Tectonic mode switches and the nature of orogenesis." Lithos 113.1-2 (2009): 274-291.

[12] Evarts, R. C., \& RC, E. The geology and petrology of the Del Puerto ophiolite, Diablo Range, central California Coast Ranges. (1977).

[13] Miyashiro, A., The Troodos complex was probably formed in an island arc: Earth and 
Planetary Science Letters, (1973) v. 19, p. 218-224, doi: 10.1016/0012-821X (73)901 18-0.

[14] Pearce, J. A., Alabaster, T., Shelton, A. W., \& Searle, M. P. The Oman ophiolite as a Cretaceous arc-basin complex: evidence and implications. Philosophical Transactions of the Royal Society of London. Series A, Mathematical and Physical Sciences, (1981). 300(1454), 299-317.

[15] Kakar M.I., Mahmood K., Khan M., Kasi A.K. and Manan R.A. Petrology and geochemistry of gabbros from the Muslim Bagh Ophiolite: implications for their petrogenesis and tectonic setting. Journal of Himalayan Earth Science, (2013). 46(1).

[16] Bédard, J. H. Cumulate recycling and crustal evolution in the Bay of Islands ophiolite. The Journal of Geology, (1991). 99(2), 225-249.

[17] Gnos, E., Khan, M., Mahmood, K., Villa, I.M., Khan, A.S., Age and tectonic setting of the Ras Koh ophiolites, Pakistan. Acta Mineralogica Pakistanica (2000). 11, 105118.

[18] Siddiqui, R.H. Crustal Evolution of the Chagai-Raskoh Arc Terrane, Balochistan, Pakistan. Unpublished PhD Thesis, National Centre of Excellence in Geology, University of Peshawar, Pakistan. 2004.

[19] Nicholson, K. N., M. Khan, and K. Mahmood. "Geochemistry of the Chagai-Raskoh arc, Pakistan: Complex arc dynamics spanning the Cretaceous to the Quaternary." Lithos 118.3-4 (2010): 338-348. [20] Jones, A.G. Reconnaissance Geology of Part of West Pakistan. A Colombo Plan
Cooperative Project, Govt. of Canada, Toronto, (Hunting Survey Corporation Report) 1961. p. 550

[21] Arthurton, R.S., Farah, A., Ahmed, W. The Late Cretaceous-Cenozoic history of western Balochistan, Pakistan - the northern margin of the Makran subduction complex. In: Leggett, J.K. (Ed.), Trench Fore-Arc Geology. Geological Society London, Special Publication, (1982). 10, pp. 343-385.

[22] Siddiqui $R H_{\text {., Jan } M} Q$., Khan $M A$. Petrogenesis of Late Cretaceous Lava Flows from a Ceno-Tethyan Island Arc: The Raskoh Arc, Balochistan, Pakistan. J Asian Earth Sci. (2012). 59: 24-28.

[23] Abdel-Gawad, M. Wrench movement in the Balochistan arc and relation to Himalayan-Indian ocean tectonics. Geological Society of America Bulletin (1971). 82, 1235-1250.

[24] Siddiqui $R \quad H$. Magmatic evolution of Chagai-Raskoh arc terrane and its implication for porphyry copper mineralization. Geologica (1996). 2: 87-119.

[25] Jacob, K.H., Quittmeyer, R.L., The Makran region of Pakistan and Iran. Geodynamics of Pakistan. Geology Survey Pakistan, (1979) pp. 303-317

[26] Vredenburg, E. W. Recent artesian experiments in India. Office of the Geological survey. (1901).

[27] Coogan L.A., Jenkin G.R. and Wilson R.N. Constraining the cooling rate of the lower oceanic crust: a new approach applied to the Oman ophiolite. Earth and Planetary Science Letters, (2002). 199(1-2), 127-146. 
[28] Thy P. Magmas and magma chamber evolution, Troodos ophiolite. Cyprus. Geology, (1987). 15(4), 316-319.

[29] Parlak O., HÖck V. and Delaloye $M$. Suprasubduction zone origin of the PozantiKarsanti ophiolite (southern Turkey) deduced from whole-rock and mineral chemistry of the gabbroic cumulates. Geological Society, London, Special Publications, (2000). 173(1), 219-234.

[30] Dilek Y. and Eddy C.A. The Troodos (Cyprus) and Kizildag (S. Turkey) ophiolites as structural models for slow-spreading ridge segments. The Journal of Geology, (1992). 100(3), 305-322.

[31] Saccani E. and Photiades A. Mid-ocean ridge and supra-subduction affinities in the Pindos ophiolites (Greece): implications for magma genesis in a forearc setting. Lithos, (2004). 73(3), 229-253.

[32] Girardeau J., Mercier J.C.C. and Xibin W. Petrology of the mafic rocks of the Xigaze ophiolite, Tibet. Contributions to Mineralogy and Petrology, (1985). 90(4), 309-321.

[33] Gnos E., Khan M., Mehmood K., Khan A.S., Naseer A. and Igor M.V. Bela Oceanic lithosphere assemblage and its relation to the Reunion hot spot. (1998). Terra Nova, 10, 90-95.
[34] Cannat M., Sauter D., Mendel V., Ruellan E., Okino K., Escartin J., Combier V. and Baala M. (2006). Modes of seafloor generation at a melt-poor ultraslowspreading ridge. Geology, 34, 605-608.

[35] Popal A., Kakar M.I. and Khan M. Geology and Petrology of Gabbroic rocks from the Khanozai Ophiolite, Northwestern Pakistan (2019)..

[36] Kakar M.I., Kerr A.C., Mahmood K., Collins A.S., Khan M. and MCDonald I. (2014). Suprasubduction zone tectonic setting of the Muslim Bagh Ophiolite, northwestern Pakistan: insights from geochemistry and petrology. Lithos, 202, 190-206.

[37] Boudier F., Nicolas A. and Ildefonse B. Magma chambers in the Oman ophiolite: fed from the top and the bottom. Earth and Planetary Science Letters, (1996) 144(1-2), 239-250.

[38] Kelemen P. and Aharonov E.. Periodic formation of magma fractures and generation of layered gabbros in the lower crust beneath oceanic spreading ridges. in Faulting and Magmatismat Mid-Ocean Ridges, Geophys. Monogr. (1998). Ser., edited by R. W. Buck et al., 106, 267-289. AGU, Washington, D. C.

Received: 04 June 2021. Revised/Accepted: 29 June 2021.

This work is licensed under a Creative Commons Attribution 4.0 International License. 